\title{
Investigating waste on new product development: case study
}

\author{
Eduardo Gomes Salgado ${ }^{a}$, Carlos Henrique Pereira Mellob, Fabiano Leal ${ }^{b}$, Carlos Eduardo Sanches da Silva ${ }^{b}$ \\ Universidade Federal de Alfenas \\ bUniversidade Federal de Itajubá \\ e-mails: egsalgado@yahoo.com.br; carlos.mello@unifei.edu.br
}

\begin{abstract}
New product development (NPD) is getting more and more significant for business competitiveness due to the increasing market globalization, products diversity and variety, and reduced life cycle. This work aimed mainly to identify waste within the NPD of a company. This was obtained through a qualitative research conducted through a case study, in order to identify enterprise waste in the PDP. The research analysis unit selected was a multinational enterprise in Brazil. This enterprise develops holders used on test tables for wire harnesses, with short, medium and long product development cycles. The results suggest that it is possible to identify wastes in NPD and improve the performance.
\end{abstract}

Keywords: lean product development, new product development, lean manufacturing, case study, lean development.

\section{Introduction}

The importance of the New Product Development (NPD) has increased significantly in the last years. The search for innovation and for the launch of new products with market acceptance is a significant concern of a variety of enterprises in economic sectors. In the industrial sector, for instance, aerospace, automotive, electronics, pharmaceutical, and furniture sectors, among others, the NPD performance is crucial (TYAGI; SAWHNEY, 2010; DE BRENTANI; KLEINSCHMIDT; SALOMO, 2010; SALGADO et al., 2014a). In this way, more approaches to product development appear in the literature. Researchers have identified a wide array of approaches: sequential phases for new product development, product platforms, concurrent engineering, waterfall models, stage-gate models, spiral development, capability maturity model, design for six sigma (DFSS), product lifecycle management (PLM) and lean product development (BASSLER et al., 2011; BULLINGER; FÄHNRICH; MEIREN, 2003; JOORE; BREZET, 2014; KOUFTEROS et al., 2014; ROZENFELD et al., 2006; DE PAULA; FOGLIATTO; CRISTOFARI, 2012). However, the scope of this paper is related exclusively to Lean product Development.

The scientific approach to lean philosophy was initially introduced by the works of Womack, Jones and Roos (1990), Shingo (1981), Womack and Jones (1996) and Hines et al. (2004), and eventually applied to the product development process. Researches by Karlsson and Åhlström (1996), Bauch (2004), Machado (2006) and Salgado et al. (2014b) focused on the evaluation of the potentialities of applying the lean philosophy in the areas of research and development, verification of implementation difficulties of lean development, waste proposition for lean development and a procedure to implement the lean philosophy in the PDP following the project structure, respectively. The research works, previously cited, mention the use of value stream mapping as a means for identifying waste in the PDP. However, they are limited to approach it theoretically not describing any empirical application, which is the contribution of this study.

Based on the above mentioned, we can assume that the identification and mitigation of waste factors (time, unnecessary activities, rework, etc.) in the product development process can reduce the lead time of this process and bring a competitive advantage for an organization.

The case study method was adopted for this paper. Yin (2005) defines case study as an empirical research that investigates a contemporary phenomenon within its real-life context, especially when the boundaries between a phenomenon and the context are not clearly defined. The case study research faces a technically unique situation in which there will be many more variables of interest than data points and, as a result, it is based on several sources of evidence, with the data needing to converge to a triangle format (considering triangulation as a means of collecting data from theory, empirical evidence and from the researcher's contribution); and, as another result, it benefits from the prior development of theoretical propositions to guide the collection and analysis of data. 
This method was adopted because it is the most suitable for exploratory research in order to answer the following research question: What are the lean approach wastes in the product development process of a company in the automobile industry? How can these wastes be identified?

To address this research question, the main objective of this work is to identify waste within the product development process (PDP) of a company. As secondary objectives, but also important to establish a theoretical framework that helps to achieve the main goal, this research aims to analyze the lean philosophy fundamentals in the product development process (PDP) that contribute to mitigate waste; recommend actions based on lean philosophy to mitigate waste in the PDP studied.

To achieve these goals, an exploratory literature review was initially conducted to identify relevant variables and raise the main wastes inherent to the PDP. Later, a case study was conducted in a multinational company based in Brazil. Interview techniques, document analysis and direct observation of processes were used for collecting data. The key interviewees were the person in charge of the project department and staff, who are responsible for the company's PDP, the commercial department manager, and the person in charge of the computer-aided manufacturing (CAM) area.

\section{Literature review}

Product Development Process (PDP) refers to the steps, activities, tasks, stages and decisions involving the project of developing a new product or service, or the improvement on an existing project, from the initial idea to the discontinuation of the product, in order to systematize the process. This process identifies customer desires which are translated into specifications to be developed in order to generate business and technical solutions. All this linked to strategy, restrictions and operational possibilities of the company and to customer needs (SALGADO; SALOMON; MELLO, 2012). Although many enterprises are aware of NPD importance on business development in a long-term period and efforts are still present on the path of NPD enhancement, failure rates of new product is high. There are many reasons for these high failure rates, being that one of the most significant ones is the low application of models, tools and techniques to support NPD (GONZÁLEZ; PALÁCIOS, 2002; RUNDQUIST; CHIBBA 2004; YEH; PAI; YANG, 2010; CHANDRA; NEELANKAVIL, 2008). To identify NPD success or to identify its collapse has been one of the main goals of many researchers in the last years.

In addition, Lean philosophy is a systematic approach for identifying and eliminating waste through continuous improvement in pursuit of perfection, using a pullcontrol strategy derived from customers' requirements (LU, YANG and WANG, 2011). The concept of manufacturing management encompassing a lean philosophy was introduced, in the 1980 s, by a research group at Massachusetts Institute of Technology (MIT), after studying the Japanese style of production, principally the Toyota Production System (TPS), in the 1980s (WOMACK et al., 1990). In the past 20 years, much attention has focused on lean manufacturing (RANKY, 2003; AGYAPONGKODUA et al., 2009; BROWNING; HEATH, 2009). However, most of previous researchers mainly focused on assembly manufacturing environment, few researches by using Value Stream Maping, a lean tool, to solve machine shop industries.

Usually, Lean is associated with manufacturing, however, there are attempts to transfer these principles, tools and techniques to other processes, such as New Product Development (NPD) (BAINES et al., 2006; HOPPMANN et al., 2011; SALGADO et al., 2014b; PERNSTÅL; FELDT; GORSCHEK, 2013). Furthermore, the research conducted by Rozenfeld et al. (2006) pointed out the existence of different approaches to PDP. Among all, one of the most cited in the literature is the lean approach in PDP, also known by the term lean development, which brings the following contributions: a more organic view of the process, achieved through the maximum simplification of the work of the teams involved, focused on prototyping and testing activities; the possibility of delaying, to the maximun extent, very specific detailed decisions, since the time spent on these details should be invested in the search for alternative solutions and understanding the project problem. However, one of the foremost reasons for this paper is that lean product development is still considered as a relatively new approach to NPD and therefore it still lacks a systematic comparison with other approaches for NPD.

\section{Case study}

\subsection{Selecting the analysis unit}

The company selected as the object of study is Emdep Brazil Ltda, which has plants in Spain, Mexico, Morocco, Nicaragua, Honduras, Romania, Tunisia and Brazil, and is located in Itajubá, state of Minas Gerais, Brazil.

Each product requested by the customer needs to be developed, that is, the client provides a sample by which the process of product development begins, so that EMDEP works on a make to order basis. Product models developed by EMDEP are distinguishable by:

a) Innovation issues;

b) complexity of development;

c) development time;

d) development cost; 
The company's main product is called ROB, Ring Out Board. The ROB is the equipment responsible for the electrical approval of product components, according to requirements set by customers. Each product requested by the customer needs to be developed, that is, the customer provides a sample by which the process of product development begins, so EMDEP works on a make to order basis. This fact can characterize the enterprise as an extreme case, as cited by Yin (2005), supporting the grounds for selecting this enterprise for the study. The PDP in EMDEP consists of the sales processes, project, and computer-aided manufacturing (CAM). The enterprise defines CAM for the area responsible for the computer design, corresponding partially to the product development process.

In addition, comparing the PDP of the company under study with a reference model, as proposed by Rozenfeld et al. (2006), it can be observed that due to the size of the company, several stages of the reference model are performed by one department or even by the same person.

Since the objective of this research is to identify wastes of the product development process, considering the development macro-phase of the model proposed by Rozenfeld et al. (2006), this macro-phase refers specifically to the informational, conceptual and detailed stages of project, not including the pre- and post-development macro-phases.

Due to the size of the company, the commercial department was not object of study for acting in the predevelopment phases. The manufacturing department in the company under study operates from the production preparation to the post-development phases. In this context, the internal processes of the company that fall into the phases of the model studied are the design and CAM departments.

\subsection{Identifying wastes}

For the qualitative research, a semi-structured interview was applied, using the research protocol. The research was conducted with four interviewees from the design department. At the end of the interview, it was possible to identify some wastes in the company's product development process.

During the interviews, the waste of waiting was initially addressed. It was observed that this waste is present in the company, because even improving the development process; it still needs to wait for characteristics sent by the customer and by the commercial department. Designer 2 (the most experienced) said:

We have waiting in product development, but it has been decreasing. Customers sometimes are slow to send the email with the part model, so we need to wait for their e-mail, delaying our product development. Other features that hinder product development is regarding the definition of test criterion, different nomenclature, delays in sending samples and special components (Special Pins). Around 10\% of the projects are on hold [...] For example, project No 07B937 has not yet been completed due to the lack of a sample. It was supposed to be delivered eight days ago, but it hasn't been delivered yet. Another case is Project No 07B963, which also lacks a sample and has been on hold for two months so far. Another example is Project No $08 B 048$ which was delivered to the client, but lacks the approval, without which we cannot conclude the project.

Another waste observed during the study is related to transport, which is characterized by the flow of information and parts.

This waste is also present in the company under study, as stated by Designer 2 " [...] our server is very fast, very good, and has been updated in recent months, but it is already full! The design part is already crowded! It hinders service because you need to save a design and you cannot. We had to delete older designs to be able to save new ones [...]". In addition, Designer 2 also claims that even with efficient communication, there are still problems regarding the flow of information:

\begin{abstract}
We have a direct communication channel with the commercial department and among designers, but everything is registered via e-mail, generating developmental delays. When we have a doubt, it goes to the commercial department so they can check with the customer. We have questions every day, which may be due to missing information, incomplete information or a missing sample. Around $10 \%$ of projects coming in await customer response, which leads to a one-day delay. Any holder may present these problems.
\end{abstract}

The transport waste is more evident when the commercial department, which sends all information and all parts to the PDP, cannot deliver it, explains Designer 2:

[...] work orders lack information, because when it is duplication in the project, the problem could be resolved in the commercial department, since they have direct contact with the customer. Projects that require, for example, continuity as tests, require the sample. Duplication projects have their samples stored, and it is the commercial department that looks for it in our storage cabinet. But when they can't find the sample, we need to help them. When there is a change in the wiring harness, they have to send a new sample [...]

Unnecessary movement was another waste verified in the object of study. Designer 2 states:

[...] we do not need to move around a lot between areas, not even within the department. We need to move around only to make copies on the machine that is at the center of the room and to check rework. In reworks, we have to go to the final inspection area to check the problem. The 
Company Regulations (internal procedures) is on the table and the server already has the standard. Projects come to us through the commercial department. We don't need to go to the commercial department to pick up the projects. When we need to claim something, it is done by e-mail [...]

In this case, the presence of movement until the final testing area to verify rework, the need for copies and the movement to assist the commercial department to find samples, characterizes the presence of this kind of waste.

Regarding the waste of inadequate processes, Designer 2 explains:

[...] the implementation of EMDEP Group (Global Design Management - GDM), which was done in all EMDEP plants around the world, has helped us gain time, because $70 \%$ of projects have already been made in the plants. Before, we used to spend 30 minutes, now we spend around five minutes for certain types of project. The basic worksheet was standardized, which made us save time in product development $[\ldots]$

In addition, she states "[...] personnel experience is good. I have been working at ENDEP for seven years, Designer 3 for five years but he is actually in the project department for a year and a half. Designer 4 is still in the training phase, but has been with us for nine months. Designer 5 has been here for a year $[\ldots] "$ ".

Regarding equipment capacity and the approach (lean, by design, etc.), and the way of developing products (traditional or simultaneous), Designer 2 explains: "We have the latest tools regarding product development software. We use Solidworks, but there is already an update for it awaiting release in Spain. All computers were updated, they were replaced by DELL computers, due to its high video quality, which helps our development [...]" and "[...] we have the company regulations that assist us in the development process. They are used to facilitate our work. Our work is set in flowcharts and SIPOC (process map). Our development process is more sequential because the information goes through areas, one after the other. It's not worth doing our activities differently."

Thus, even with a few characteristics of inadequate processes waste, we can say that a sequential development could be better used by the company, featuring a waste. Another feature of the process is that calipers are used to measure all dimensions, which could be facilitated by a 3D scanner. This device automatically checks all quotas, increasing productivity.

Designer 2 states that, "[...] although using a conventional measurement system, the tolerances required for the parts are achieved without major problems $[\ldots]$ ".

Another waste found was the inventory. Designer 2 justifies that:
[...] all projects are stored physically and electronically. Physically, they are stored for five years. However, you cannot tell, because they are all mixed together. Samples that deteriorate are segregated and discarded. The creation of a program for the EMDEP group facilitated the electronic location of previous projects, streamlining product development. Before, we had a folder with photos of projects we did, but spent a long time looking for an equal or similar project [...]

The company is unaware of how long the projects are stored. Furthermore, some older projects need to be deleted and all samples need to be stored. This may characterize another waste: electronically, loss of knowledge generated or loss of projects that would be reused may occur.

The company conducts testing on $100 \%$ of products to meet customers' request. However, Designer 2 says that the testing is performed only at the end, which can affect the product development: "[...] at the end of production, tests of all types are performed in holders developed by the project, which will help ensure if the development was successful or not. The tests performed contribute in the final stage of product development and also in future work [...]"

Regarding the company's ability to serve its projects, featuring the overproduction waste, Designer 2 explains that "[...] on average, one project per hour can be done in the development. The ideal is developing five pneumatic projects per day. EMDEP Spain defined eight pneumatic projects per day as ideal, but I cannot tell you how they calculated this capability by designer [...]". Thus, this waste was characterized as overproduction, because there is no synchronization between the time considered for development and the capability, as defined per Bauch (2004).

Another waste identified by this study was related to defects. Designer 2 states:

[...] the computer program that we use has a command that says when a component is in conflict with another. $A$ verification in pairs helps to prevent the error from reaching the CAM department. The CAM department also checks if there is a problem. But the most common faults are: tight or loose silhouette, lack of continuity, sealing, lock or clip failure and lack of identification on the board, which can arise in the PDP $[\ldots]$

Furthermore,

[...] previous designs are used for the development of new products and nowadays they are easily found due to the program released for the group. When we have a new project to disseminate the knowledge acquired during this development, we gather the other designers to see how it was done. The commercial department is also called to participate. It is like a workshop [...]

Thus, the waste of defect was considered in this product development process in the company under study. It was 
found that in November 2007, rework occurred in the orders 07B718, 07B880, 07B844 and 07B675. Currently, there are many filters in the production that help prevent rework of more complex projects.

Regarding the waste of reinvention, Designer 2 states that "[...] even with the creation of the program for the EMDEP Group, we still have a rate of approximately two per cent of poor project reuse. This can be and must be improved. Before our rate of poor project reuse was around $20 \%$." Poor reuse of previous projects was another waste identified in the PDP of the company under study.

The wastes of lack of discipline and limitations on IT resources were not identified during the interview, but they were later identified by observation of the researcher, probably because the company has the process of product development in the scope of certification by the standard ISO 9001. Designer 2 states that:

[...] the goals and objectives are well defined. For example, we have to reach a maximum of two percent in rework. This indicator is to be revised, but our current goal is this. We are managing to achieve this goal, but we believe and know that we can and have to improve [...]" "The responsibilities and authorities are well defined and are known by everyone in the responsibility matrix and job descriptions [...]" "The level of cooperation from other departments/people is very good, the production department aids in the development; the commercial department aids in customer contact, with special projects, requesting more samples when necessary; the senior management assists on the resources and within our department, collaboration is great [...]

She adds that: "[...] a survey of the need for internal and external training is made every end of year. The top management assesses the survey and decides what training they will release resources for [...]" "We achieved the goals for expected rework, as well as for projects delivered on time. One of the problems that mostly occurred before was the lack of attention, which no longer occurs due to the Solidworks software."

Therefore, at the end of the interview, it was possible to identify some wastes in the company's product development process. Tables 1 and 2 show a comparison between the wastes identified in the company's Project and CAM departments with the wastes cited by Bauch (2004) for the development of products.

Table 1. Identified waste features in the case study.

\begin{tabular}{|c|c|c|c|c|c|}
\hline \multicolumn{2}{|c|}{ Waste } & \multirow[b]{2}{*}{ Comments on relevant waste reasons } & \multicolumn{3}{|c|}{ Data collection } \\
\hline Theoretical & Empirical & & Interview & Observation & $\begin{array}{c}\text { Document } \\
\text { analysis }\end{array}$ \\
\hline Waiting & $\begin{array}{l}\text { Waiting for the project to } \\
\text { be approved }\end{array}$ & $\begin{array}{l}\text { Incomplete service orders (project specifications), } \\
\text { lack of connectors sample or damaged connectors }\end{array}$ & $\mathrm{X}$ & $\mathrm{X}$ & $\mathrm{X}$ \\
\hline \multirow{3}{*}{ IT resource limitations } & $\begin{array}{l}\text { Incompatibility } \\
\text { problems }\end{array}$ & $\begin{array}{l}\text { Files from clients, with extensions, that are } \\
\text { incompatible with the software used in the enterprise. }\end{array}$ & $\mathrm{X}$ & & \\
\hline & $\begin{array}{l}\text { Too much time wasted } \\
\text { to locate past projects in } \\
\text { the software }\end{array}$ & $\begin{array}{l}\text { In some projects, it was observed waste of time trying } \\
\text { to look for designs already done using the enterprise } \\
\text { software. }\end{array}$ & & $\mathrm{X}$ & \\
\hline & Process capacity & $\begin{array}{l}\text { It was necessary to send designs to the headquarters, } \\
\text { since the designs had not been registered at GDM. }\end{array}$ & & & $\mathrm{X}$ \\
\hline $\begin{array}{l}\text { Unnecessary } \\
\text { movement }\end{array}$ & $\begin{array}{l}\text { Staff's excessive } \\
\text { movement }\end{array}$ & $\begin{array}{l}\text { Part of the resources (copies, physical files, CAM, } \\
\text { etc.) used in the PDP requires the employee to move } \\
\text { significantly from his workplace. }\end{array}$ & $\mathrm{X}$ & $\mathrm{X}$ & \\
\hline \multirow[t]{2}{*}{ Reinvention } & $\begin{array}{l}\text { Poor reuse of } \\
\text { knowledge. }\end{array}$ & $\begin{array}{l}\text { The formation of a company's designer is mainly } \\
\text { done on the job. However, the small number of } \\
\text { designers and the high number of projects does not } \\
\text { allow acquirement and socialization of the knowledge } \\
\text { generated. Moreover, the exchange of knowledge } \\
\text { among units in other countries occurs informally } \\
\text { when the designer is partially allocated in other unit to } \\
\text { meet the increasing project demands. The corporative } \\
\text { mechanism of knowledge management is restricted } \\
\text { to the project records. }\end{array}$ & $\mathrm{X}$ & $\mathrm{X}$ & $\mathrm{X}$ \\
\hline & Poor reuse of projects. & $\begin{array}{l}\text { All projects are registered; however, its indexation } \\
\text { among plants in other countries was not present. With } \\
\text { the implementation of a unified database, project } \\
\text { duplication had a considerable reduction. However, } \\
\text { there are still projects that were not registered. }\end{array}$ & $\mathrm{X}$ & $\mathrm{X}$ & $\mathrm{X}$ \\
\hline Defects & $\begin{array}{l}\text { Rework - Erroneous } \\
\text { information about } \\
\text { projects }\end{array}$ & $\begin{array}{l}\text { Reworks found were due to erroneous information } \\
\text { such as tight silhouette, incompatible taps, uncertainty } \\
\text { of terminal alignments and bad connector bracing. }\end{array}$ & $\mathrm{X}$ & $\mathrm{X}$ & $\mathrm{X}$ \\
\hline
\end{tabular}


Table 2. Wastes identified in the product development in the enterprise, which is the object of study.

\begin{tabular}{|l|c|c|}
\hline \multicolumn{1}{|c|}{ Wastes/ areas } & Design (Project) & CAM \\
\hline Waiting & $\mathrm{X}$ & $\mathrm{X}$ \\
\hline Transport & $\mathrm{X}$ & $\mathrm{X}$ \\
\hline Unnecessary movement & $\mathrm{X}$ & $\mathrm{X}$ \\
\hline Inadequate processes & $\mathrm{X}$ & $\mathrm{X}$ \\
\hline Inventory & $\mathrm{X}$ & $\mathrm{X}$ \\
\hline Overproduction & $\mathrm{X}$ & $\mathrm{X}$ \\
\hline Defects & $\mathrm{X}$ & $\mathrm{X}$ \\
\hline Reinvention & $\mathrm{X}$ & $\mathrm{X}$ \\
\hline Lack of discipline & $\mathrm{O}$ & $\mathrm{O}$ \\
\hline IT resource limitations & $\mathrm{X}$ & $\mathrm{O}$ \\
\hline \multicolumn{2}{|l|}{ X-identified waste $\mathrm{O}-$ Non-identified waste }
\end{tabular}

$\mathrm{X}$ - identified waste. $\mathrm{O}$ - Non-identified waste.

\section{Conclusions}

Lean thinking is not only a different production model that alters the usual manufacturing ways on a production line. Its implementation is a general shift in the company, mainly on people's culture and can be applied across the company, including the process of product development.

The overall objective of this paper was reached. As supported by the observations of the process by the researcher, interviews with key informants and documentary analysis, we could identify the wastes of waiting, transport, unnecessary movement, inadequate processes, inventory, overproduction, defects, reinvention and limitations on IT resources in the PDP of the company under study.

However, the waste of lack of discipline was not identified by the researcher during the study. One possible reason for this was the fact that the company has the certification of its quality management system by ISO 9001, and the process of product development is part of the scope. It suggests that companies that have a quality management system certified with a reference model for the implemented PDP may have less waste of lack of discipline in the process of product development.

The results of this study suggest that lean wastes occur as a result of the fulfillment of all the product development process, and that it was not possible to determine if there is a higher incidence of such wastes in any of the specific phases (project planning, conceptual design, detailed design, etc.) of the PDP.

The principles of lean thinking (value, value stream, flow, pull production and perfection) can be applied to the PDP. The application of these principles in the company can bring improvements to the product development process, as they contribute to the mitigation of wastes.

Suggestions for continuing the study: conduct a study for the prioritization of lean tools in the implementation of lean thinking in the new product development department; propose performance indicators for measuring and monitoring the process of lean product development; identify and analyze the impacts of wastes in the product development process of incubated technology-based companies; and verify that wastes are influenced by the type of project (innovation, evolution, variation and reverse).

\section{Acknowledgments}

The authors would like to thank the CAPES Foundation, (Process PE024/2008), the FAPEMIG Foundation (Processes: APQ-00976-13; TEC-PPM-00520/13 and TECPPM-00058-13) and the CNPq (Processes: 249160/20137, 310660/2012-2, 401082/2014-8 and 478509/2012-0), that without their support, this work would be impossible. In addition, the authors thank the interviewees, by their information, patience and devoted time for this work.

\section{References}

AGYAPONG-KODUA, K.; AJAEFOBI, J. O.; WESTON, R. $\mathrm{H}$. Modelling dynamic value streams in support of process design and evaluation. International Journal of Computer Integrated Manufacturing, v. 22, n. 5, p. 411-427, 2009. http://dx.doi.org/10.1080/09511920802527574.

BAINES, T. et al. State-of-the-art in lean design engineering: a literature review on white collar lean. Journal of Engineering Manufacture, v. 220, n. 9, p. 1539-1547, 2006. http://dx.doi.org/10.1243/09544054JEM613.

BASSLER, D. et al. A comparison of the integration of risk management principles in product development approaches. In: INTERNATIONAL CONFERENCE ON ENGINEERING DESIGN (ICED 11), 18., 2011, Copenhagen. Proceedings... The Design Society, 2011. p. 306-316.

BAUCH, C. Lean product development: making waste transparent. 2004. $140 \mathrm{f}$. Tese-Technical University of Munich, Munich, 2004.

BROWNING, T. R.; HEATH, R. D. Reconceptualizing the effects of lean on production costs with evidence from the F-22 program. Journal of Operations Management, v. 27 , n. 1 , p. $23-44,2009$. http://dx.doi.org/10.1016/j. jom.2008.03.009.

BULLINGER, H. J.; FÄHNRICH, K. P.; MEIREN, T. Service engineering - methodical development of new service products. International Journal of Production Economics, v. 85, n. 3, p. 275-287, 2003. http://dx.doi. org/10.1016/S0925-5273(03)00116-6.

CHANDRA, M.; NEELANKAVIL, J. Product development and innovation for developing countries: potential and challenges. Journal of Management Development, v. 27, n. 10, p. 1017-1025, 2008. http://dx.doi. org/10.1108/02621710810916277.

DE BRENTANI, U.; KLEINSCHMIDT, E. J.; SALOMO, S. Success in global new product development: impact 
of strategy and the behavioral environment of the firm. Journal of Product Innovation Management, v. 27, n. 2, p. 143-160, 2010. http://dx.doi.org/10.1111/j.15405885.2010.00707.x.

DE PAULA, I. C.; FOGLIATTO, F. S.; CRISTOFARI, C. A. Method for assessing the maturity of product development management : a proposal. African Journal of Business Management, v. 5, n. 38, p. 10285-10302, 2012. http:// dx.doi.org/110.5897/AJBM10.1553.

GONZÁLEZ, F. J. M.; PALACIOS, T. M. B. The effect of new product development techniques on new product success in Spanish firms. Industrial Marketing Management, v. 31, n. 3, p. 261-271, 2002. http://dx.doi.org/10.1016/S00198501(00)00150-4.

HINES, P.; HOLWEG, M.; RICH, N. Learnig to envolve: a review of contemporany lean thinking. International Journal of Operations \& Production Management, v. 24, n. 10, p. 994-1011, 2004. http://dx.doi. org/10.1108/01443570410558049.

HOPPMANN, J. et al. A framework for organizing lean product development. Engineering Management Journal, v. 23, n. 1, p. 3-16, 2011. http://dx.doi.org/10.1080/10429247.2 011.11431883 .

JOORE P, BREZET H. A multilevel design model: the mutual relationship between product-service system development and societal change processes. Journal of Cleaner Production, v. 97, n. 15, p. 92-105, 2014. http://dx.doi. org/10.1016/j.jclepro.2014.06.043.

KARLSSON, C.; ÅHLSTRÖM, P. The difficult path to lean product development. Journal of Product Innovation Management, v. 13, n. 4, p. 283-295, 1996. http://dx.doi. org/10.1016/S0737-6782(96)00033-1.

KOUFTEROS, X. et al. Product development practices, manufacturing practices, and performance: a mediational perspective. International Journal of Production Economics, v. 156, p. 83-97, 2014. http://dx.doi. org/10.1016/j.ijpe.2014.05.017.

LU, J.-C.; YANG, T.; WANG, C.-Y. A lean pull system design analysed by value stream mapping and multiple criteria decision-making method under demand uncertainty. International Journal of Computer Integrated Manufacturing, v. 24, n. 3, p. 211-228, 2011. http://dx.doi. org/10.1080/0951192X.2010.551283.

MACHADO, M. C. Princípios enxutos no processo de desenvolvimento de produtos: proposta de uma metodologia para implementação. 2006. 265 f. Tese (Doutorado em Engenharia de Produção)-Escola Politécnica, Universidade de São Paulo, São Paulo, 2006.

PERNSTÅL, J.; FELDT, R.; GORSCHEK, T. The lean gap: a review of lean approaches to large-scale software systems development. Journal of Systems and Software, v. 86, n. 11, p. 2797-2821, 2013. http://dx.doi.org/10.1016/j. jss.2013.06.035.

RANKY, P. G. Network simulation models of lean manufacturing systems in digital factories and an intranet server balancing algorithm. International Journal of Computer Integrated Manufacturing, v. 16, n. 4-5, p. 267-282, 2003. http:// dx.doi.org/10.1080/0951192031000089174.

ROZENFELD, H. et al. Gestão de desenvolvimento de produtos: uma referência para a melhoria do processo. São Paulo: Saraiva, 2006.

RUNDQUIST, J.; CHIBBA, A. The use of processes and methods in NPD: a survey of swedish industry. International Journal of Innovation and Technology Management, v. 1, n. 1, p. 37-54, 2004. http://dx.doi. org/10.1142/S0219877004000076.

SALGADO, E. G. et al. A reference model for the new product development in medium-sized technology- based electronics enterprises. Revista IEEE América Latina, v. 12, n. 8, p. 1341-1348, 2014a. http://dx.doi.org/10.1109/ TLA.2014.7014499.

SALGADO, E. G. et al. Waste investigation on product development process using the lean and simulation approaches. Product: Management \& Development, v. 12, n. 1, p. 3-13, 2014b. http://dx.doi.org/10.4322/ pmd.2014.001.

SAlGADO, E. G.; SAlOMON, V. A. P.; MELlO, C. H. P. Analytic hierarchy prioritisation of new product development activities for electronics manufacturing. International Journal of Production Research, v. 50, n. 17, p. 4860-4866, 2012. http://dx.doi.org/10.1080/002075 43.2012.657972.

SHINGO, S. A study of the Toyota production system from an industrial engineering viewpoint. Cambridge: Productivity Press, 1981.

TYAGI, R. K.; SAWHNEY, M. S. High-performance product management: the impact of structure, process, competencies, and role definition. Journal of Product Innovation Management, v. 27, n. 1, p. 83-96, 2010. http:// dx.doi.org/10.1111/j.1540-5885.2009.00701.x.

WOMACK, J. P.; JONES, D. T.; ROOS, D. The machine that changed the world. New York: Macmillan, 1990.

WOMACK, P. J.; JONES, D. T. Lean thinking: banish waste and create wealth in your corporation. New York: Simon \& Schuster, 1996.

YEH, T. M.; PAI, F. Y.; YANG, C. C. Performance improvement in new product development with effective tools and techniques adoption for high-tech industries. Quality \& Quantity, v. 44, n. 1, p. 131-152, 2010. http://dx.doi. org/10.1007/s11135-008-9186-7.

YIN, R. Estudo de caso: planejamento e métodos. 3. d. Porto Alegre: Bookman, 2005. 